\title{
PENERAPAN METODE ANALYTICAL HIERACHY PROCESS (AHP) DAN SIMPLE ADDITIVE WEIGHTING (SAW) DALAM SISTEM PENUNJANG KEPUTUSAN PEMILIHAN PEGAWAI TERBAIK PADA UNIT PENGELOLA GRAHA RAYA STUDI KASUS PERUSAHAAN PROPERTI
}

\author{
Raka Fitra Pradana ${ }^{1)}$, Joko Sutrisno ${ }^{2)}$ \\ ${ }^{1}$ Sistem Informasi, Fakultas Teknologi Informasi, Universitas Budi Luhur \\ ${ }^{1,2} \mathrm{Jl}$. Raya Ciledug, Petukangan Utara, Kebayoran Lama, Jakarta Selatan 12260 \\ E-mail: rakafitrap@gmail.com ${ }^{1)}$, joko.sutrisno@budiluhur.ac.id ${ }^{2)}$
}

\begin{abstract}
Abstrak
Kinerja pegawai yang kompeten dan produktif merupakan idaman bagi setiap perusahaan dengan melakukan pengolahan sumber daya manusia yang optimal, Pegawai yang mempunyai kinerja kompeten dan produktif dapat membantu perusahaan dalam bersaing, Untuk menciptakan kinerja pegawai yang kompeten dan produktif penerapan penghargaan atas pegawai terbaik menjadi salah satu cara untuk menciptakan persaingan yang sehat. Penghargaan pegawai terbaik berdasarkan penilaian kinerja pegawai yang diukur melalui beberapa kriteria yang memenuhi standar, dengan menerapkan sistem penunjang keputusan diharapkan membantu dalam penilaian dengan baik. Terdapat hasil penilaian yang sama dan pemrosesan data kandidat yang cukup lama menjadi kendala dalam proses pengambilan keputusan menjadi kurang optimal. Sistem yang akan dibuat ini menggunakan metode Analytical Hierarchy Process (AHP) untuk menentukan bobot kriteria dan metode Simple Additive Weighting (SAW) digunakan untuk menentukan pegawai terbaik dengan menghasilkan perankingan alternatif. Dengan adanya sistem penunjang keputusan ini, diharapkan dapat membantu pengambil keputusan dalam menentukan pegawai terbaik sehingga menghasilkan keputusan maksimal dan tepat.
\end{abstract}

Kata kunci: sistem penunjang keputusan, AHP, SAW, Pemilihan Pegawai Terbaik.

\section{PENDAHULUAN}

Pegawai merupakan bagian dari sebuah perusahaan, dalam mengembangkan usaha dibutuhkan Sumber daya manusia atau pegawai yang kompeten dan produktif yang dapat memberi nilai positif sebagai daya saing perusahaan. Pengelolaan sumber daya sebagai salah satu kunci dalam mengembangkan perusahaan dengan mengelola sumber daya manusia sehingga menciptakan sumber daya manusia yang kompeten dan produktif.

Dengan pengelolaan sumber daya manusia yang baik akan menciptakan tenaga kerja yang kompeten, produktif dan dapat membantu perusahaan berkembang dengan baik dan mampu bersaing dengan perusahaan yang lain, tenaga kerja yang mampu memberikan nilai positif dalam pengembangan bisnis perusahaan adalah sebuah dambaan setiap perusahaan. Penghargaan atas kinerja pegawai merupakan salah satu cara dalam meningkatkan kinerja pegawai dengan menciptakan suasana persaingan secara sehat di antara pegawai sebagai bentuk strategi untuk meningkatkan semangat kerja pegawai. Pelayanan terbaik yang diberikan pegawai adalah suatu hal yang diharapkan dari pihak perusahaan maupun pelanggan dalam proses bisnis.
Pemilihan pegawai terbaik dan teladan sudah sepatutnya di aplikasikan di suatu perusahaan sebagai salah satu strategi meningkatkan kinerja pegawai, sementara pemilihan secara subjektif hanya akan menimbulkan suatu kerancuan dan ke tidak tepatan dalam pemilihan pegawai yang memungkinkan menciptakan situasi yang tidak harmonis antara pegawai, untuk menghindari ketidakadilan tentang siapa yang bertanggung jawab dan siapa yang mengerjakan serta menentukan siapa yang berhak dan tidaknya atas penghargaan tersebut, dengan proses penilaian yang cukup lama dikarenakan pengumpulan data dan perhitungan belum dibantu komputerisasi dan sering terdapat nilai akhir yang sama. Berdasarkan kondisi tersebut, dibutuhkan sistem yang dapat membantu pihak management dalam proses pemilihan pegawai terbaik, berdasarkan kondisi tersebut penulis menggunakan metode Analytical Hierarchy Process (AHP) yang digunakan untuk menentukan bobot nilai berdasarkan kriteria yang digunakan dan Simple Additive Weighting (SAW) yang digunakan untuk menghitung total nilai alternatif yang nantinya dapat digunakan sebagai perangkingan nilai alternatif. Dengan Penggunaan metode tersebut diharapkan dapat membantu pihak management dalam pemilihan pegawai terbaik. 


\section{METODE PENELITIAN}

\subsection{Sistem Penunjang keputusan}

Turban [1], Berpendapat Sistem penunjang keputusan adalah alat bantu dalam proses pengambilan keputusan. Dan Turban [2] berpendapat bahwa konsep struktur pada definisi awal sistem pendukung keputusan (bahwa sistem pendukung keputusan dapat menangani situasi semistruktur dan tidak terstruktur hanya dengan memperhatikan si pengambil keputusan atau suatu spesifik. Jadi mereka mendefinisikan DSS sebagai sistem yang dapat diperluas untuk mampu mendukung analisis data ad hoc dan pemodelan keputusan, berorientasi terhadap perencanaan masa depan, digunakan pada interval yang tidak reguler dan tak terencana. Dapat disimpulkan bahwa sistem penunjang keputusan adalah suatu sistem informasi spesifik yang ditujukan untuk membantu manajemen dalam mengambil keputusan yang berkaitan dengan persoalan yang bersifat semi terstruktur. Sistem penunjang keputusan ditunjukan untuk keputusankeputusan yang memerlukan penilaian atau pada keputusan-keputusan tidak terstruktur.

\subsection{Analytical Hierarchy Process(AHP)}

Sukenda [3], Berpendapat Analytical Hierarchy Process (AHP) dikembangkan oleh Thomas L. Saaty berfungsi sebagai pemecah masalah yang kompleks menjadi sub-sub dan disusun menjadi bentuk hierarki, Prioritas dan pengukuran konsistensi. Dengan begitu AHP mempunyai 3 prinsip memecahkan masalah yaitu penyusunan hierarki, penentuan prioritas, dan pengukuran konsistensi.

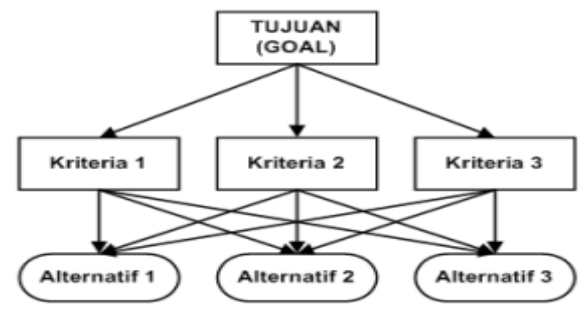

Gambar 1. Struktur Hierarki

Penyusunan hierarki dilakukan dengan cara mengidentifikasi pengetahuan atau informasi yang sedang diamati. Penyusunan tersebut dimulai dari permasalahan yang kompleks yang diuraikan menjadi elemen pokoknya, elemen pokok ini diuraikan lagi ke dalam bagian-bagiannya lagi, dan seterusnya secara hierarki.

Penilaian setiap level hierarki dinilai melalui perbandingan berpasangan. Dan Saaty [4], berpendapat skala 1 sampai 9 adalah skala terbaik dalam mengekspresikan pendapat pada berbagai persoalan. Pada skala 1-9 digunakan sebagai pertimbangan antara elemen dengan membandingkan pasangan elemen pada setiap level hierarki.

Tabel 1. Tabel Nilai Perbandingan

\begin{tabular}{ll}
\hline Kepentingan Keterangan \\
\hline 1 & $\begin{array}{l}\text { Kedua elemen sama pentingnya } \\
\text { Elemen yang satu sedikit lebih penting dari pada } \\
\text { elemen yang lainnya }\end{array}$ \\
5 & $\begin{array}{l}\text { Elemen yang satu lebih penting dari pada elemen } \\
\text { yang lainnya }\end{array}$ \\
7 & $\begin{array}{l}\text { Elemen yang satu sangat lebih penting dari pada } \\
\text { elemen yang lainnya } \\
\text { Elemen yang satu mutlak dari pada elemen yang } \\
9\end{array}$ \\
$2,4,6,8$ & $\begin{array}{l}\text { lainnya } \\
\text { Nilai antara dua nilai pertimbangan yang }\end{array}$ \\
\hline
\end{tabular}

Skala dengan sembilan satuan dapat menggambarkan sejauh mana kita dapat membedakan intensitas hubungan antar elemen.

Dan Pada Setiap level hierarki akan dilakukan perbandingan antar elemen untuk menentukan prioritas (Pairwaise Comparisons). Dan dengan membandingkan antar elemen dengan setiap elemen berdasarkan tingkat hierarki untuk menentukan prioritas atau relatif pentingnya elemen.

Semua elemen yang sudah dibandingkan satu sama lain antar elemen dengan tingkat yang sama akan dihitung konsistensinya untuk membuktikan bahwa perbandingan antar elemen sudah dilakukan dengan baik. Pengujian dilakukan dengan cara uji Consistency indeks (CI) dan Consistency ratio (CR)

Berikut rumus uji Consistency indeks(CI):

$$
\mathrm{CI}=\frac{\lambda_{\max }-\mathrm{n}}{\mathrm{n}-1}
$$

Diketahui:

$\mathrm{n}$ : ordo matriks

$\lambda_{\max }-\mathrm{X} \quad$ : nilai eigen terbesar matriks berordo $n$

CI : rasio penyimpangan konsistensi

Untuk mengetahui CI mempunyai nilai yang cukup baik atau tidak, hal yang harus diketahui adalah nilai uji CR(Consistency Ratio) yang mempunyai nilai kurang dari 0,1.

Marimin dan Magfiroh [5], berpendapat Consistency Rasio (CR) sebagai parameter terhadap perbandingan berpasangan untuk diperiksa jika perbandingan dikatakan konsisten atau tidak.

Berikut rumus Consistency Ratio(CR):

$$
C R=\frac{C I}{R I}
$$

CI : Consistency Index

RI : Random Index 
CR : Consistency Ratio

Dan Oarkridge laboratory yang mengeluarkan nilai RI(Random Index) berupa tabel.

Tabel 2. Tabel Nilai Random Index

\begin{tabular}{ccccccccccc}
\hline$n$ & 1 & 2 & 3 & 4 & 5 & 6 & 7 & 8 & 9 & 10 \\
\hline$R I$ & 0 & 0 & 0.58 & 0.90 & 1.12 & 1.24 & 1.32 & 1.41 & 1.45 & 1.49 \\
\hline
\end{tabular}

\subsection{Simple Additive Weighting (SAW)}

Kusumadewi [6], berpendapat metode Simple Additive Weighting(SAW) sebagai penjumlahan terbobot dari rating kinerja pada setiap alternatif pada semua atribut yang nantinya akan dinormalisasi dengan matriks keputusan.

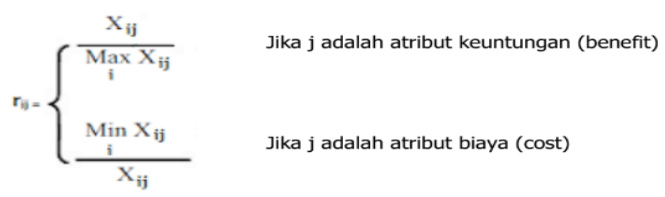

Dengan $\mathrm{r}_{\mathrm{ij}}$ adalah rating kinerja ternormalisasi dari alternatif $A_{i}$ pada atribut $C_{j} ; I=1,2, . ., m$ dan $\mathrm{j}=1,2, . ., n$.

Dengan menentukan kriteria yang dijadikan acuan pengambilan keputusan dilanjutkan dengan menentukan nilai bobot dari masing-masing kriteria dan menentukan rating kecocokan setiap alternatif pada setiap kriteria. Kriteria dinormalisasi berdasarkan jenis atribut seperti benefit atau cost dan memberikan nilai prefensi untuk setiap alternatif $\left(\mathrm{V}_{\mathrm{i}}\right)$ dengan rumus:

$$
\mathbf{V}_{\mathrm{i}}=\sum_{\mathrm{j}=1}^{\mathrm{n}} \mathbf{w}_{\mathrm{j}} \mathbf{r}_{\mathrm{ij}}
$$

$\mathrm{V}_{\mathrm{i}}$ : rank setiap alternatif

$\mathrm{W}_{\mathrm{i}}$ : nilai bobot dari setiap kriteria

$\mathrm{R}_{\mathrm{ij}}$ : nilai rating kinerja ternormalisasi

Hasil akhir yang diperoleh dari perangkingan perkalian matriks ternormalisasi $\mathrm{R}$ dengan vector bobot yang menghasilkan nilai terbesar yang akan dipilih sebagai nilai alternatif terbaik.

\section{HASIL DAN PEMBAHASAN}

\subsection{Analisa Masalah}

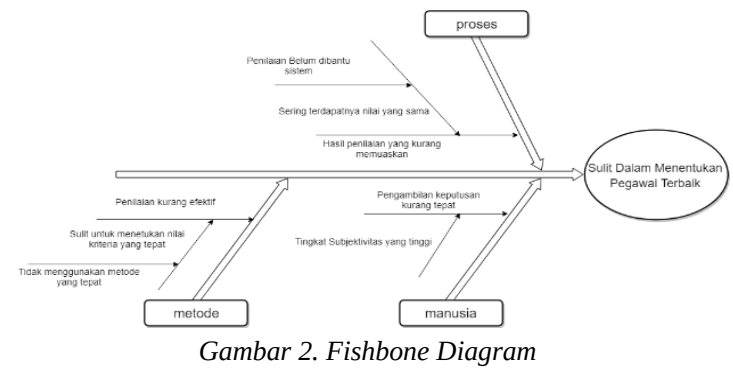

Untuk menganalisa masalah penulis menggunakan fishbone diagram atau fishbone ishikawa.

\subsection{Analisa Rancangan Proses Bisnis}

Proses penilaian pegawai terbaik selain berdasarkan penilaian bagian manajer juga memerlukan rekapitulasi absensi sebagai salah satu kriteria, data absensi diperoleh dari bagian administrasi, setelah data nilai dari setiap kriteria sudah terpenuhi proses perhitungan dapat di lakukan dengan menggunakan sistem, setelah nilai sudah ditampilkan bagian manajer unit akan melakukan pengambilan keputusan.

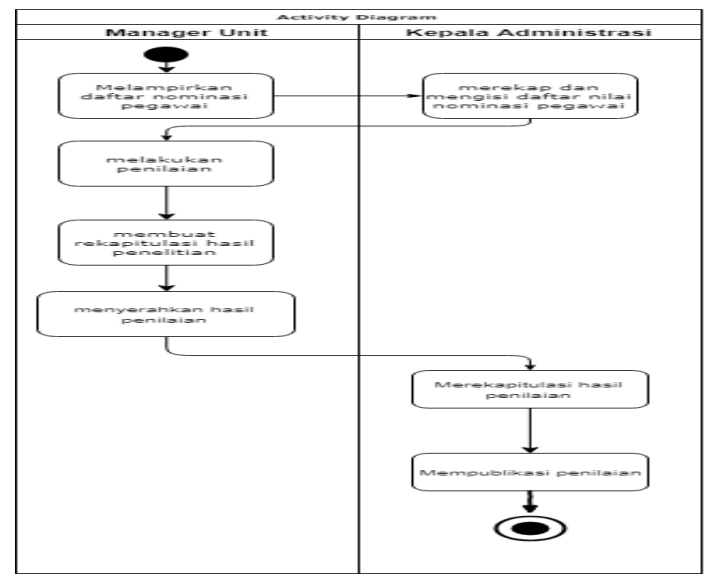

Gambar 3. Activity Diagram

\subsection{Identifikasi Kriteria}

Berikut kriteria yang digunakan dalam penilaian yaitu: Tanggung jawab, Kedisiplinan, Sopan santun dan kehadiran.

Dengan menggunakan prinsip kerja AHP sebagai mana kriteria yang digunakan akan di bandingkan satu sama lain dengan yang mempunyai tingkat yang sama. Berikut perbandingan antar kriteria:

a) Nilai Tanggung jawab 3(tiga) kali lebih penting dari Kedisiplinan

b) Nilai Tanggung jawab 5(lima) kali lebih penting dari Sopan santun

c) Nilai Tanggung jawab 7(tujuh) kali lebih penting dari Kehadiran

d) Nilai Kedisiplinan 3(tiga)kali lebih penting dari Sopan santun

e) Nilai Kedisiplinan 5(lima) kali lebih penting dari Kehadiran

f) Nilai Sopan santun 3(tiga) kali lebih penting dari Kehadiran

\subsection{Model Analytical Hierarchy Process(AHP)} berikut: 
A) Penentuan bobot kriteria

Tabel 3. Tabel Perbandingan

\begin{tabular}{lllll}
\hline Banding & K1 & K2 & K3 & K4 \\
\hline K1 & $1 / 1$ & $3 / 1$ & $5 / 1$ & $7 / 1$ \\
K2 & $1 / 3$ & $1 / 1$ & $3 / 1$ & $5 / 1$ \\
K3 & $1 / 5$ & $1 / 3$ & $1 / 1$ & $3 / 1$ \\
K4 & $1 / 7$ & $1 / 5$ & $1 / 3$ & $1 / 1$ \\
\hline \multicolumn{5}{c}{ K1 : Tanggung jawab } \\
K2 : Kedisiplinan & \\
K3 : Sopan santun & & \\
\multicolumn{3}{c}{ K4 : Kehadiran } & &
\end{tabular}

Setelah didapat nilai matriks perbandingan kriteria data tersebut dijabarkan menjadi bentuk desimal

$\left(\begin{array}{lll}1,000 & 3,0005,000 & 7,000 \\ 0,333 & 1,0003,000 & 5,000 \\ 0,200 & 0,3331,000 & 3,000 \\ 0,143 & 0,2000,333 & 1,000\end{array}\right)$

Dan selanjutnya mengalikan matriks dengan dirinya sendiri(iterasi ke 1).

$$
\left(\begin{array}{llll}
1,000 & 3,000 & 5,000 & 7,000 \\
0,333 & 1,000 & 3,000 & 5,000 \\
0,200 & 0,333 & 1,000 & 3,000 \\
0,143 & 0,200 & 0,333 & 1,000
\end{array}\right) \times\left(\begin{array}{llll}
1,000 & 3,000 & 5,000 & 7,000 \\
0,333 & 1,000 & 3,000 & 5,000 \\
0,200 & 0,333 & 1,000 & 3,000 \\
0,143 & 0,200 & 0,333 & 1,000
\end{array}\right)
$$

berikut hasil dari perkalian matriks iterasi ke-1

$$
\left(\begin{array}{cccc}
3,993 & 9,065 & 21,331 & 44,000 \\
1,981 & 3,998 & 9,333 & 21,331 \\
0,940 & 1,866 & 3,998 & 9,065 \\
0,419 & 0,940 & 1,981 & 3,9997
\end{array}\right)
$$

Dilanjutkan dengan menjumlahkan setiap baris hasil dari perkalian matriks iterasi ke 1

$$
\left(\begin{array}{c}
78,389 \\
36,635 \\
15,865 \\
7,323
\end{array}\right)
$$

Dan didapat total sebesar: 138,213. Selanjutnya Langkah menormalisasikan dengan membagi setiap jumlah baris dengan total baris untuk menghasilkan eigenvector iterasi ke 1 :

$$
\left(\begin{array}{l}
78,389 \\
36,635 \\
15,865 \\
7,323
\end{array}\right) \quad\left(\begin{array}{c}
0,56716 \\
0,26506 \\
0,11479 \\
0,05298
\end{array}\right)
$$

Berdasarkan dari normalisasi tersebut dapat disimpulkan nilai persentase bobot sebagai berikut:

Tabel 4. Tabel Persentase bobot

\begin{tabular}{ll}
\hline Kriteria & Bobot(persentase) \\
\hline Tanggung Jawab & $56,716 \%$ \\
Kedisiplinan & $26,506 \%$ \\
Sopan Santun & $11,479 \%$
\end{tabular}

\begin{tabular}{ll} 
Kehadiran & $5,298 \%$ \\
Total & $100 \%$ \\
\hline
\end{tabular}

B) Pengujian Konsistensi

Hal yang dilakukan pertama kali adalah mengalikan bilangan desimal dengan eigenvector

$$
\left(\begin{array}{llll}
1,000 & 3,000 & 5,000 & 7,000 \\
0,333 & 1,000 & 3,000 & 5,000 \\
0,200 & 0,333 & 1,000 & 3,000 \\
0,142 & 0,200 & 0,333 & 1,000
\end{array}\right) \times\left(\begin{array}{l}
0,56716 \\
0,26506 \\
0,11479 \\
0,05298
\end{array}\right)
$$

Yang menghasilkan nilai:
g) Tanggung Jawab
$: 2,30715$
h) Kedisiplinan :1,06319
i) Sopan Santun :0,47543
j) Kehadiran

Selanjutnya menghitung konsistensi vector dengan menentukan nilai rata-rata dengan membagi hasil dari perhitungan sebelumnya dengan eigenvector iterasi ke2

$$
\left(\begin{array}{l}
2,30715 \\
1,06319 \\
0,47543 \\
0,22475
\end{array}\right):\left(\begin{array}{l}
0,56716 \\
0,26506 \\
0,11479 \\
0,05298
\end{array}\right)=\left(\begin{array}{l}
4,0679 \\
4,0112 \\
4,1417 \\
4,2422
\end{array}\right)
$$

Dilanjutkan dengan menghitung nilai rata-rata dari konsistensi vektor.

$$
\frac{(4,0679+4,0112+4,1417+4,2422)}{4}=4,1157
$$

Berikutnya menghitung nilai konsistensi indeks (CI) dengan Rumus:

$$
\begin{aligned}
& \frac{\lambda-n}{n-1}=C I \\
& \frac{4,1157-4}{4-1}=0,0385
\end{aligned}
$$

Dan didapat nilai CI sebesar: 0,0385

Dan tahapan perhitungan nilai Consistency Rasio (CR) diperlukan nilai Random Index (RI) berasal dari tabel Oarkridge, untuk nilai Random Index (RI) dikarenakan kriteria yang digunakan berjumlah 4 (empat) maka nilai RI adalah: 0,90.

$$
\begin{aligned}
& \frac{C I}{R I}=C R \\
& \frac{0,0385}{0,90}=C R \\
& C R=0,0427
\end{aligned}
$$

Berdasarkan Perhitungan di atas dapat diketahui nilai Consistency Ratio (CR) sebesar 0,0427. Dikarenakan nilai CR tidak lebih besar dari 0,1 maka disimpulkan konsistensi pada perbandingan kriteria cukup baik dan tidak perlu melakukan perhitungan ulang.

\subsection{Model Simple Additive Weighting(SAW)}

Metode ini digunakan untuk penjumlahan bobot dan mencari nilai alternatif pada atribut. Dengan mengetahui nilai alternatif berdasarkan 
pengelompokan kriteria didapat nilai alternatif sebagai berikut:

Tabel 5. Tabel Nilai Alternatif

\begin{tabular}{lllll}
\hline & K1 & K2 & K3 & K4 \\
\hline Ria & 86 & 96 & 96 & 96 \\
Ivan & 90 & 90 & 96 & 92 \\
Noni & 76 & 98 & 96 & 100 \\
Irvan & 88 & 100 & 98 & 92 \\
Rana & 88 & 96 & 100 & 100 \\
\hline
\end{tabular}

Dan diketahui sifat/atribut (Keuntungan/biaya) dari kriteria yang digunakan.

Tabel 6. Tabel atribut kriteria

\begin{tabular}{ll}
\hline Kriteria & Atribut \\
\hline K1(Tanggung Jawab) & Benefit \\
K2(Kedisiplinan) & Benefit \\
K3(Sopan Santun) & Benefit \\
K4(Kehadiran) & Benefit \\
\hline
\end{tabular}

Dan dengan menghitung berdasarkan atribut dari kriteria yang digunakan dengan menggunakan rumus:

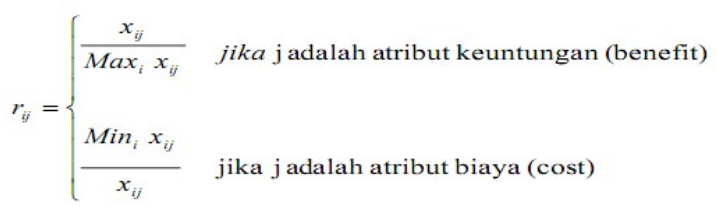

$\mathrm{R}_{\mathrm{ij}} \quad$ : nilai rating kinerja ternomalisasi

$\mathrm{X}_{\mathrm{ij}} \quad$ : nilai atribut setiap kriteria

kriteria i

Max $\mathrm{x}_{\mathrm{ij}} \quad$ : nilai terbesar alternatif setiap

kriteria i

Min $\mathrm{x}_{\mathrm{ij}} \quad$ : nilai terkecil alternatif setiap

Benefit : jika nilai terbesar yang terbaik

Cost : jika nilai terkecil yang terbaik

Dikarenakan setiap kriteria yang digunakan termasuk golongan keuntungan/Benefit maka rumus yang digunakan adalah rumus keuntungan/ benefit.

1) Perhitungan nilai tanggung jawab(K1)

$$
\begin{aligned}
& \mathrm{R}_{11} \frac{86}{90}=0,956 \\
& \mathrm{R}_{21} \frac{90}{90}=1 \\
& \mathrm{R}_{31} \frac{76}{90}=0,844 \\
& \mathrm{R}_{41} \frac{88}{90}=0,978 \\
& \mathrm{R}_{51} \frac{88}{90}=0,978 \\
& 2) \frac{\text { Perhitung }}{2} \\
& \mathrm{R}_{12} \frac{96}{100}=0,96 \\
& \mathrm{R}_{22} \frac{90}{100}=0,9 \\
& \mathrm{R}_{32} \frac{98}{100}=0,98 \\
& \mathrm{R}_{42} \frac{100}{100}=1
\end{aligned}
$$

2) Perhitungan nilai kedisiplinan(k2)
$\mathrm{R}_{52} \frac{96}{100}=0,96$

3) Perhitungan nilai sopan santun(k3)
$\mathrm{R}_{13} \frac{96}{100}=0,96$
$\mathrm{R}_{23} \frac{96}{100}=0,96$
$\mathrm{R}_{33} \frac{96}{100}=0,96$
$\mathrm{R}_{43} \frac{98}{100}=0,98$
$\mathrm{R}_{53} \frac{100}{100}=1$

4) Perhitungan Nilai kehadiran $(\mathrm{k} 4)$

$$
\begin{aligned}
& \mathrm{R}_{14} \frac{96}{100}=0,96 \\
& \mathrm{R}_{24} \frac{92}{100}=0,92 \\
& \mathrm{R}_{34} \frac{100}{100}=1 \\
& \mathrm{R}_{44} \frac{92}{100}=0,92 \\
& \mathrm{R}_{54} \frac{100}{100}=1
\end{aligned}
$$

Setelah nilai normalisasi alternatif sudah didapatkan, selanjutnya dihitung dengan nilai kriteria.

Tabel 7. Tabel Nilai normalisasi

\begin{tabular}{lllll}
\hline & K1 & K2 & K3 & K4 \\
\hline Ria & 0,956 & 0,96 & 0,96 & 0,96 \\
Ivan & 1 & 0,9 & 0,96 & 0,92 \\
Noni & 0,844 & 0,98 & 0,96 & 1 \\
Irvan & 0,978 & 1 & 0,98 & 0,91 \\
Rana & 0,978 & 0,96 & 1 & 1 \\
bobot & 0,56716 & 0,26506 & 0,11479 & 0,05298 \\
\hline
\end{tabular}

Dan didapatkan nilai sebagai berikut

$$
\begin{aligned}
& \text { Ria }=\{(0,956 \times 0,56716)+(0,96 \times 0,26506)+ \\
& (0,96 \times 0,11479)+(0,96 \times 0,05298)\} \\
& =0,95747 \\
& \text { Ivan }=\{(1 \times 0,56716)+(0,9 \times 0,26506)+ \\
& (0,96 \times 0,11479)+(0,92 \times 0,05298)\} \\
& =0,964654 \\
& \text { Noni }=\{(0,844 \times 0,56716)+(0,98 \times 0,26506) \\
& +(0,96 \times 0,11479)+(1 \times 0,05298)\} \\
& =0,901872311 \\
& \text { Irvan }=\{(0,978 \times 0,56716)+(1 \times 0,26506)+ \\
& (0,98 \times 0,11479)+(0,91 \times 0,05298)\} \\
& =0,980852244 \\
& \text { Rana }=\{(0,978 \times 0,56716)+(0,96 \times 0,26506) \\
& \left.+(1 \times 0,11479)+\left(\begin{array}{lll}
1 & x & 0,05298
\end{array}\right)\right\} \\
& =0,976784044
\end{aligned}
$$

Dari hasil perhitungan nilai di atas dapat diketahui bahwa kandidat yang memiliki nilai tertinggi adalah irvan dengan nilai $=0,98085$.

\subsection{Entity Relationship Diagram (ERD)}

ERD digambarkan untuk mengetahui hubungan antar entity-entity yang ada dalam suatu sistem pada database. 


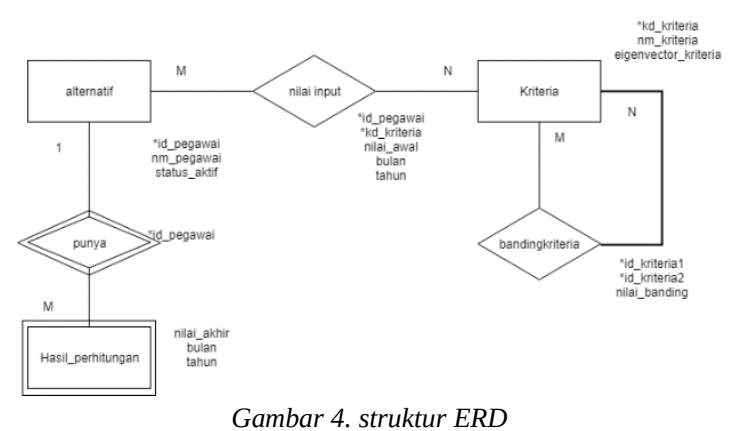

3.7. Logical Record Structure (LRS)

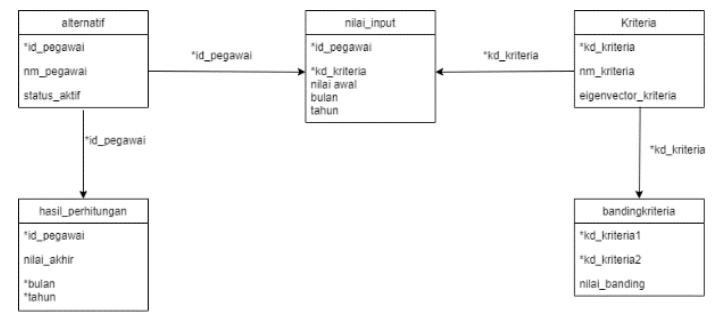

Gambar 5. Gambar Struktur LRS

Sebuah hal yang sangat terkait dalam analisa berorientasi objek, pemodelan konspetual dan pengimplementasian menggunakan ERD (entity relationship diagram) dan memiliki hubungan antar record dapat disebut LRS (Logical record structure).

\subsection{Use Case Diagram}

Use Case Diagram adalah pemodelan untuk menggambarkan behavior / kelakuan sistem yang akan dibuat. Dan sebagai penggambaran atas previlege atau hak akses akan sebuah sistem.

a) Use Case Entry

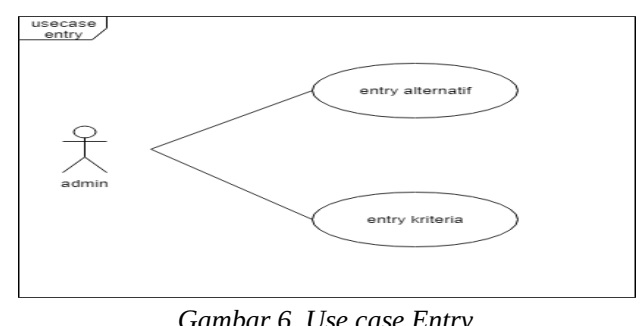

Gambar 6. Use case Entry

b) Use Case Proses

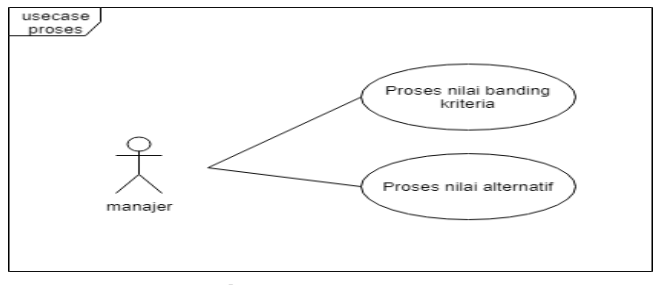

Gambar 7. Use Case Proses c) Use Case Laporan

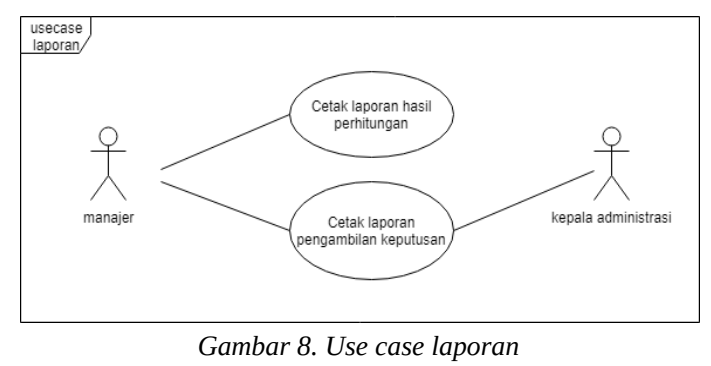

3.9. Rancangan Layar

a) Menu Utama

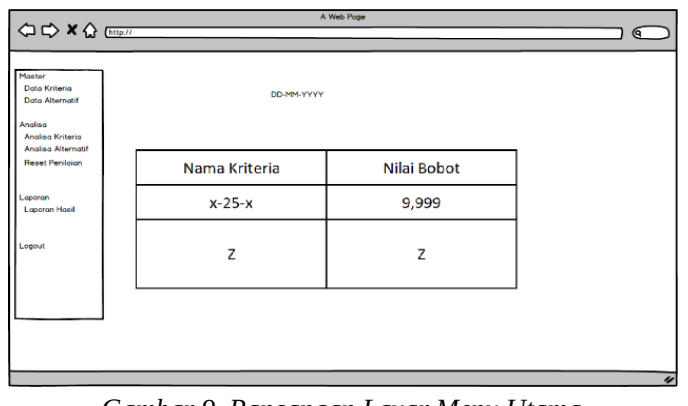

Gambar 9. Rancangan Layar Menu Utama

berikut ini adalah tampilan utama, terdapat tampilan nama kriteria dan bobot kriteria yang digunakan saat ini, pada sidebar terdapat menu master, analisa, dan laporan.

b) Menu Entry Kriteria

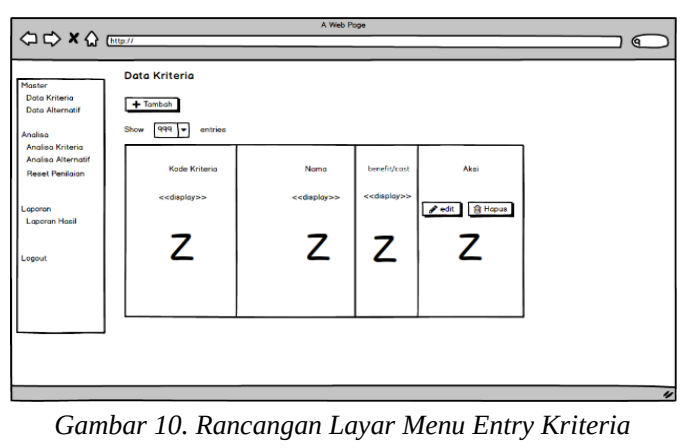

Pada menu entry kriteria ini digunakan untuk mengentry kriteria yang digunakan.

c) Menu Entry Alternatif

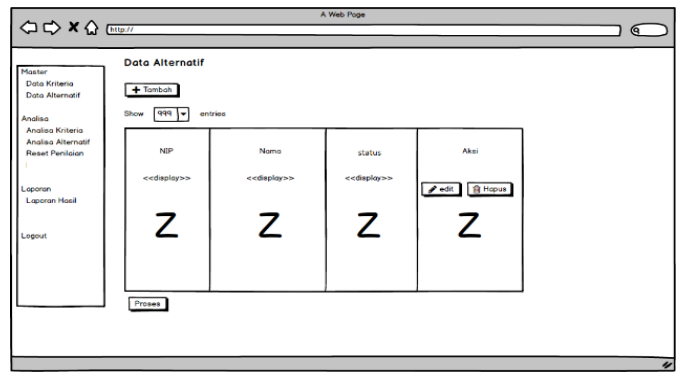

Gambar 11. Rancangan Layar Menu Entry Alternatif 
Pada menu entry alternatif digunakan untuk mengentry data alternatif atau pegawai.

d) Menu Analisa Kriteria

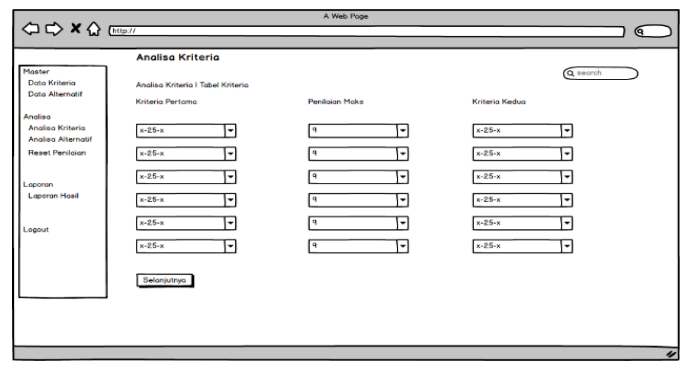

Gambar 12. Rancangan Layar Menu Analisa Kriteria

Pada menu analisa kriteria digunakan untuk perbandingan antar kriteria yang nantinya diproses menjadi bobot kriteria.

e) Menu Analisa Alternatif

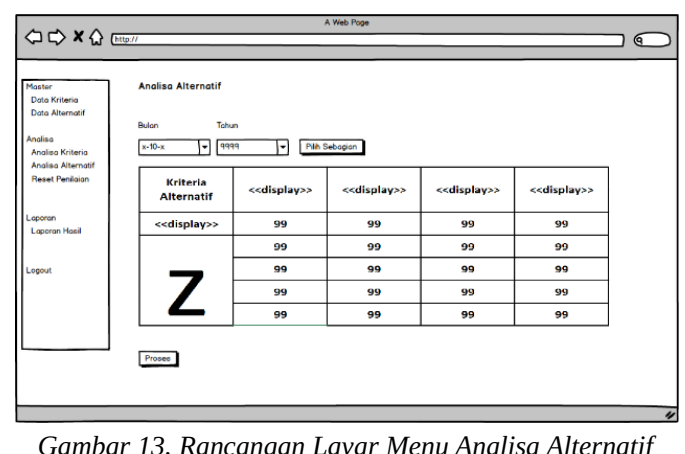

Pada Menu Analisa alternatif digunakan untuk penilaian alternatif yang nantinya akan di proses dengan bobot kriteria sehingga menghasilkan nilai yang dapat digunakan sebagai penunjang keputusan.

f) Menu Cetak Laporan

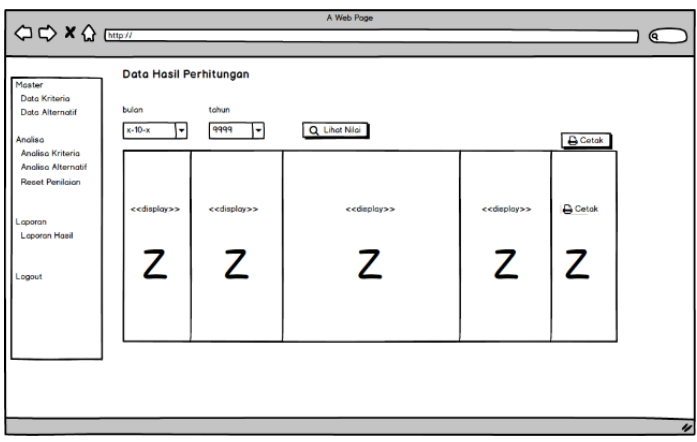

Gambar 14. Rancangan Layar Menu Cetak Laporan

pada menu ini pengguna dapat mencetak hasil perhitungan atau sebagai hasil keputusan.

\section{KESIMPULAN}

Berdasarkan hasil analisa dari bab-bab sebelumnya, penulis menyimpulkan beberapa hal sebagai berikut:

a) Dengan adanya sistem penunjang keputusan ini, diharapkan dapat membantu pihak management dalam mengambil keputusan tentang pemilihan pegawai terbaik.

b) Pembobotan yang dilakukan berdasarkan Hasil Perbandingan Antara, Menggunakan Metode AHP dapat membantu penilaian lebih optimal.

c) Penilaian terhadap perankingan alternatif dengan menggunakan metode SAW dapat membantu dalam penentuan kandidat pegawai terbaik.

d) Dan dapat disimpulkan berdasarkan penilaian perbandingan kriteria, diketahui kriteria tanggung jawab mempunyai pengaruh besar dalam penilaian dengan nilai bobot: 0,56716 dan alternatif yang menjadi kandidat kuat adalah irvan dengan nilai akhir: 0,98085.

e) Dan pengolahan data menjadi lebih cepat karena dibantu dengan sistem, sehingga proses pengambilan keputusan bisa lebih cepat.

Adapun saran dalam penggunaan sistem penunjang keputusan ini sebagai berikut:

a) Ketelitian dalam penginputan nilai perlu ditingkatkan agar pegawai yang terpilih adalah pegawai yang memang berhak menjadi pegawai terbaik.

b) Pengambil keputusan perlu mendapatkan pelatihan khusus agar dapat mengoperasikan sistem dengan optimal.

\section{DAFTAR PUSTAKA}

[1] Turban, Decission Support System and Intelligent System, 9th ed. Upper Saddle River: NJ. Prentice Hall, 2010.

[2] Turban, Decision Support Systems and Intelligent Systems, 6th ed. Upper Saddle River: NJ. Prentice Hall, 2001.

[3] Sukenda and Z. P. Afrizone, "Sistem Pendukung Keputusan Untuk Memilih Kendaraan Bekas Dengan Menggunakan Metode Analitic Hierarchy Process (AHP),” 2012

[4] T. L. Saaty, Decision making for leaders: the analytic hierarchy process for decisions in a complex world. RWS publications, 1990.

[5] Marimin and N. Maghfiroh, Aplikasi Teknis Pengambilan Keputusan dalam Manajemen Rantai Pasok. Bogor: IPB Press, 2010.

[6] S. Kusumadewi, Fuzzy Multi-Attribut Decision Making (Fuzzy MADM). Yogyakarta: Graha Ilmu, 2006. 